\title{
Molecular analysis of bacterial diversity in mudflats along the salinity gradient of an acidified tropical Bornean estuary (South East Asia)
}

\author{
Henk Bolhuis ${ }^{1 *}$, Henriette Schluepmann², Juri Kristalijn ${ }^{1}$, Zohrah Sulaiman ${ }^{3,4}$ and David J Marshall ${ }^{3}$
}

\begin{abstract}
Background: The Brunei River and Bay estuarine system (BES) in the northwest of Borneo is acidic and highly turbid. The system supports extensive intertidal mudflats and presents a potentially steep salinity and pH gradient along its length $(45 \mathrm{~km})$. Temporal variation in physical parameters is observed diurnally due to seawater flux during tidal forcing, and stochastically due to elevated freshwater inflow after rains, resulting in a salinity range between 0 and 34 psu. High velocity freshwater run-off from acid sulphate formations during monsoon seasons results in highly variable and acidic conditions $(\mathrm{pH} 4)$ at the upper reaches of the BES, whereas the $\mathrm{pH}$ is relatively stable $(\mathrm{pH} 8)$ at the seaward extremes, due to mixing with seawater from the South China Sea. At their surfaces, the BES mudflats present microbial ecosystems driven by oxygenic phototrophs. To study the effect of various physical parameters on the bacterial diversity of the BES mudflats, surface samples were collected from six sites stretching over $40 \mathrm{~km}$ for molecular and phylogentic analysis.

Results: The bacterial diversity at these sites was compared by community fingerprinting analysis using 16S rRNA gene based denaturing gradient gel electrophoresis and by $16 \mathrm{~S}$ rRNA gene sequencing and phylogenetic analyses. Results revealed functionally conserved, diatom-driven microbial mudflat communities composed of mainly novel, uncultured species. Species composition was evaluated as 50-70\% unique for each site along the BES. Clustering of the sequences commonly occurred and revealed that proteobacterial diversity was related to the salinity gradient. When considering all phyla, the diversity varied consistently with physical parameters (including anthropogenic) that are expected to influence microbial composition.
\end{abstract}

Conclusion: The BES mudflats were found to comprise the typical functional groups of microorganisms associated with photosynthetic carbon flux, sulfur cycling (Gamma- and Deltaproteobacteria), and decomposition (Bacteroidetes). From a structural perspective, however, the mudflats constituted discretely distributed communities along the physical gradient of the BES, composed of largely novel species of Bacteria. This study provides first insights into patterns of bacterial community structure in tropical South East Asian coastal ecosystems that are potentially threatened by increasing variability in $\mathrm{pH}$ and salinity, in line with predicted future environmental change.

Keywords: Marine Environmental Research, Borneo, Brunei, Mudflats, Acid sulfide, 16S rRNA, Bacterial diversity, Microbial mats

\footnotetext{
* Correspondence: henk.bolhuis@nioz.nl

${ }^{1}$ Department of Marine Microbiology, Royal Netherlands Institute of Sea Research (NIOZ), P.O. Box 140, 4400AC Yerseke, The Netherlands

Full list of author information is available at the end of the article
} 


\section{Background}

Mudflats are found all over the world in intertidal and freshwater systems. They possess an enormous water carrying capacity and therefore serve as natural coastal defence systems. They can be extremely productive and may be responsible for up to $50 \%$ of the primary production of estuaries, and thereby sustain large fish and shellfish stocks [1]. Diatoms are photosynthetic microalgae that form extensive biofilms or mats on the surface of intertidal mudflats providing a matrix in which the organisms are embedded. Diatoms are primary producers, forming large amounts of extracellular polymeric substances (EPS). These substances play an important role in sediment stabilization [2,3], but also provide an important input of organic carbon that supports a complex ecosystem, consisting of several trophic levels of organisms, ranging from macro- to micro-fauna [4]. In these estuarine environments, anoxic conditions in mudflats rapidly evolve and stimulate sulfate-reducing prokaryotes that use sulfate as the terminal electron acceptor and produce large amounts of sulfide [5]. A part of the sulfide is converted back to sulfate by sulphide-oxidizing bacteria, thus completing the sulfur cycle. A greater part of the sulfide, however, remains bound by reactive metal ions, and forms insoluble metallic precipitates, principally minerals containing $\mathrm{FeS}$ and $\mathrm{FeS}_{2}$ (iron pyrite) $[5,6]$. The bacterial sulfur cycle is largely maintained by photosynthetically produced carbon and energy sources, mainly sugars and low molecular weight organic acids such as acetate, lactate and sulfonates [7-9]. Sulfate reduction is considered as one of the main anaerobic processes in the biomineralization of up to $50 \%$ of the total organic matter in mudflat sediments [10]. The majority of studies on microbial diversity and functioning of mudflats has been undertaken in temperate regions [11-14]. Although much less is known about microbial communities in mudflats from tropical regions, information is becoming available for the subtropical Asian region [15,16].

In the tropical Brunei River and Bay estuarine system (BES) of the South East Asian island of Borneo (Figure 1), mudflat inundation is highly variable in duration and the water may vary considerably in its physical and chemical properties. The mudflats experience seasonally-changing, daily semidiurnal tidal patterns, and seasonally-variable freshwater inflow associated with monsoon and intermonsoon periods (two of each annually). At times the mudflats are exposed to desiccating conditions. Importantly, mudflats in the BES are strongly influenced by acidic freshwater running from alluvial deposits dating 5400 years ago in the valleys and older sediments on the surrounding terraces made up of acid sulfide containing soils with little to no carbonate-containing mineral to neutralize [17-19]. These acidic freshwater inflows become mixed with more basic marine water along the length of the BES. Sulfide minerals may result from the above described bacterial process occurring in the geological past as is the case for the Setap Shale in Brunei [20]. When exposed to aerobic environments by erosion or excavation, sulfide minerals will oxidize and eventually leach sulfuric acid which, if not neutralized, may cause soil $\mathrm{pH}$ to drop

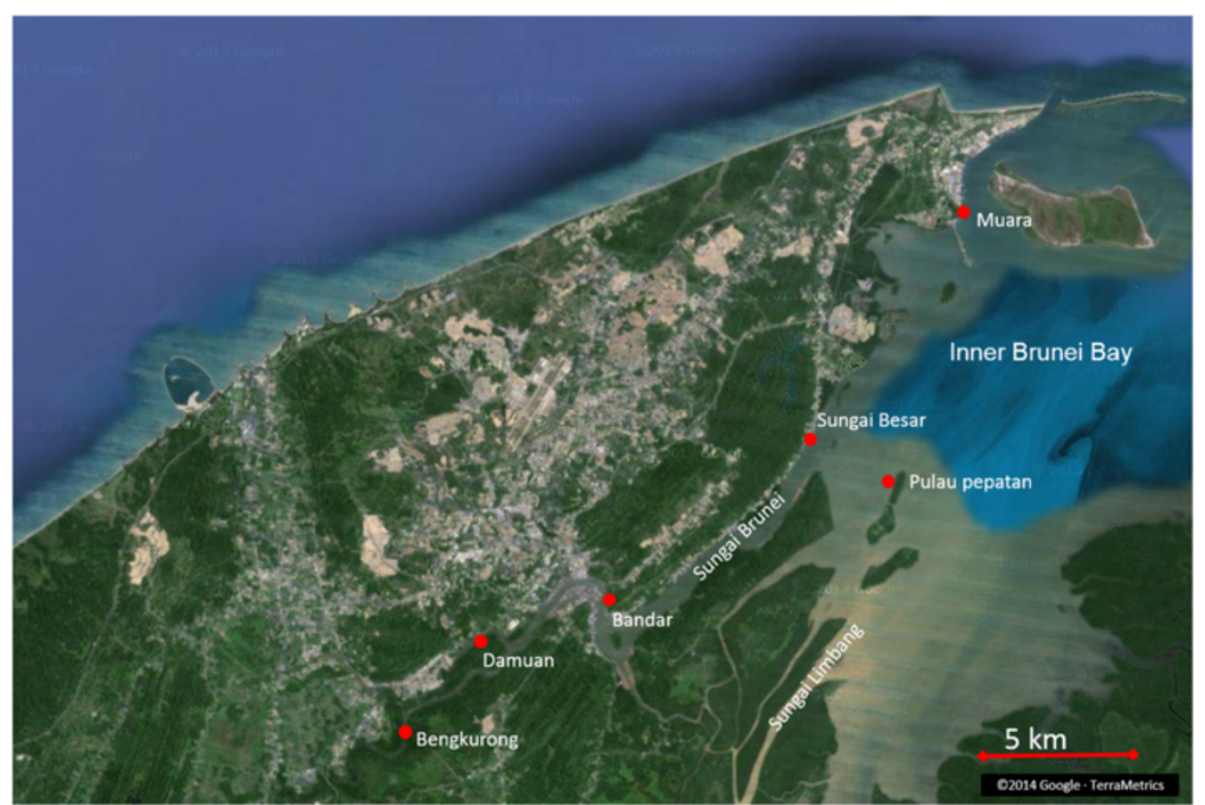

Figure 1 Map of the Brunei River and Estuary System. Sampling points are indicated by red dots. Shallow areas in the inner Brunei Bay (depth $\sim 5 \mathrm{~m}$ ) seen as brown. Daily tidal range varies between 0-2.3 $\mathrm{m}$. Relatively high turbid inflow is shown associated with Limbang River. Blue areas show the distribution of deeper channels. 
to $\mathrm{pH} 3.5$ or lower, and aluminium or heavy metals to be released [17,21-23]. Moreover, as in many estuaries, water runoff into the BES is influenced by a muddy substratum, causing turbidity that limits photosynthesis, thus limiting active withdrawal of $\mathrm{CO}_{2}$ and reducing the production of $\mathrm{O}_{2}$ [24]. Organisms inhabiting the naturally acidic BES are thus exposed to $\mathrm{pH}$ and salinity levels ranging beyond 5.8 and $8.3 \mathrm{pH}$ units and 3.58 and $31.2 \mathrm{psu}$ [25], but also to high natural (mangrove) and anthropogenic organic loads, low dissolved oxygen levels, elevated dissolved $\mathrm{CO}_{2}$ levels, and highly turbid conditions [26].

Microbial communities along natural salinity and $\mathrm{pH}$ gradients in estuaries are generally believed to play an important role in ecosystem stability [27-30]. The BES presents the opportunity to explore the microbial community composition for a tropical estuarine system, strongly influenced by acidic inflow [21]. There is heightened interest to understand the effects of acidification on patterns and processes in marine ecosystems in general, in line with the current threat of globally lowered seawater $\mathrm{pH}$, relating to the ongoing elevation of atmospheric $\mathrm{CO}_{2}$ [31,32]. In the BES, microbial community composition may on one hand be influenced by the physical ( $\mathrm{pH}$ /salinity) gradient, but microbial activity may also be directly responsible for the observed acidification through fermentation or respiratory redox chains. In the present study we used molecular tools to analyse the bacterial community composition in mudflats along the BES gradient and reveal a community largely consisting of unique species.

\section{Results}

Most of the microbial mats revealed clear photosynthetic activity with large amounts of oxygen being produced at the surface. Mat pigmentation at extraction was more brown than green suggesting the dominance of diatoms over cyanobacteria (data not shown). Only the sediments from the most seaward sampling site at Muara, which had a more sandy structure, did not visibly show oxygen production. Upon sampling all sites revealed the typical odour of sulfides, indicative of an active sulfate reducing community. At the time of sampling, we were unable to obtain accurate measurements of salinity and $\mathrm{pH}$ in the sediments. We therefore measured the $\mathrm{pH}$ and salinity of the water to which the sediments are exposed (Table 1) at maximally one meter distance from where the sample was taken. For Pulau Pepatan the sampling point was far from the water mass due to low tide and we used a puddle of water adjacent to the sampling spot instead. The salinity of the overlying water at this site is usually highly variable, being influenced by marine water at high tides and by fresh water from the Limbang River and during extensive rainfall. At time of sampling the salinity was rather low (9.3 psu) but recordings as low as 3 psu have been measured before at this site.
Table 1 Water variables at sampling points in the BES (04 November 2012)

\begin{tabular}{|c|c|c|c|}
\hline & Coordinates & Salinity (ppt) & $\mathrm{pH}$ \\
\hline Bengkurong & $4^{\circ} 49^{\prime} 09^{\prime \prime} N 114^{\circ} 51^{\prime} 43^{\prime \prime} \mathrm{E}$ & 3.04 & 4.60 \\
\hline Damuan & $4^{\circ} 52^{\prime} 08^{\prime \prime} N 114^{\circ} 54^{\prime} 42^{\prime \prime} \mathrm{E}$ & 8.12 & 7.49 \\
\hline Bandar & $4^{\circ} 53^{\prime} 10^{\prime \prime} \mathrm{N} 114^{\circ} 56^{\prime} 50^{\prime \prime} \mathrm{E}$ & 7.57 & 7.46 \\
\hline Sungai Besar & $4^{\circ} 55^{\prime} 40^{\prime \prime} \mathrm{N} 115^{\circ} 00^{\prime} 52^{\prime \prime} \mathrm{E}$ & 15.45 & 7.95 \\
\hline Muara & $5^{\circ} 00^{\prime} 23^{\prime \prime} N 115^{\circ} 03^{\prime} 57^{\prime \prime} E$ & 28.0 & 8.78 \\
\hline Pulau Pepatan & $4^{\circ} 53^{\prime} 09^{\prime \prime} N 115^{\circ} 02^{\prime} 41^{\prime \prime} \mathrm{E}$ & 9.3 & 8.15 \\
\hline
\end{tabular}

In accordance with estuary dynamics that are influenced by both freshwater from the river and marine water from the tides, the salinity increased from the upriver sampling point at Bengkurong to the most marine sampling point at Muara (Table 1). These spot recordings were consistent with more detailed high-resolution temporal data recorded simultaneously at Bandar (landward) and Keingarong ( $\left.5^{\circ} 02^{\prime} 05^{\prime \prime} \mathrm{N} 115^{\circ} 06^{\prime} 02^{\prime \prime}\right)$, near Muara, every 30 minutes, for 22 days (see Figure 2). Both diurnal (tidal) and longer-term salinity variations were greater at Bandar (ranging between 2.1 and 20.8 psu) compared to Keingarong (17.0 and $29.5 \mathrm{psu}$ ), for which the salinity regime was distinctly higher. Water temperature was similar among the stations $\left(\sim 30 \mathrm{C}^{\circ}\right)$, and $\mathrm{pH}$ closely correlated with estuarine water salinity (Figure 2).

Bacterial 16S rRNA gene DGGE analysis revealed a diverse banding pattern, indicative of a rich bacterial community (Figure 3). The triplicate samples from each location were nearly identical in composition. In contrast, comparison of the samples between locations revealed clear differences in banding pattern, although a number of shared bands were observed in samples from most locations. The mudflat samples from Pepatan Island appeared less diverse with a lower number of visible bands. Cluster analysis of the DGGE fingerprints revealed two major clusters, the first consisting of two sub-clusters containing freshwater-dominated mudflat sites with high organic load Damuan and Bandar, and of the marine-dominated mudflats Sungai Besar and Muara. The upriver site Bengkurong clustered separately with the outlier Pulau Pepatan situated in the BES bay.

Based on the large overlap in community composition revealed by DGGE, DNA extracts from replicate samples in one location were pooled to represent the unseen heterogeneity of the mat type in further molecular analysis. For each location, a 16S rRNA gene clone library was constructed from the pooled samples consisting of over 100 clones with $\sim 600$ nucleotides per read (Table 2). Richness estimators (Chao) [33] at a 97\% identity cut-off revealed the highest values of 386 and 430 operational taxonomic units (OTU's) for the two upstream freshwaterinfluenced sediment samples, Bengkurong and Damuan respectively, and the lowest richness of 192 for Bandar. The 

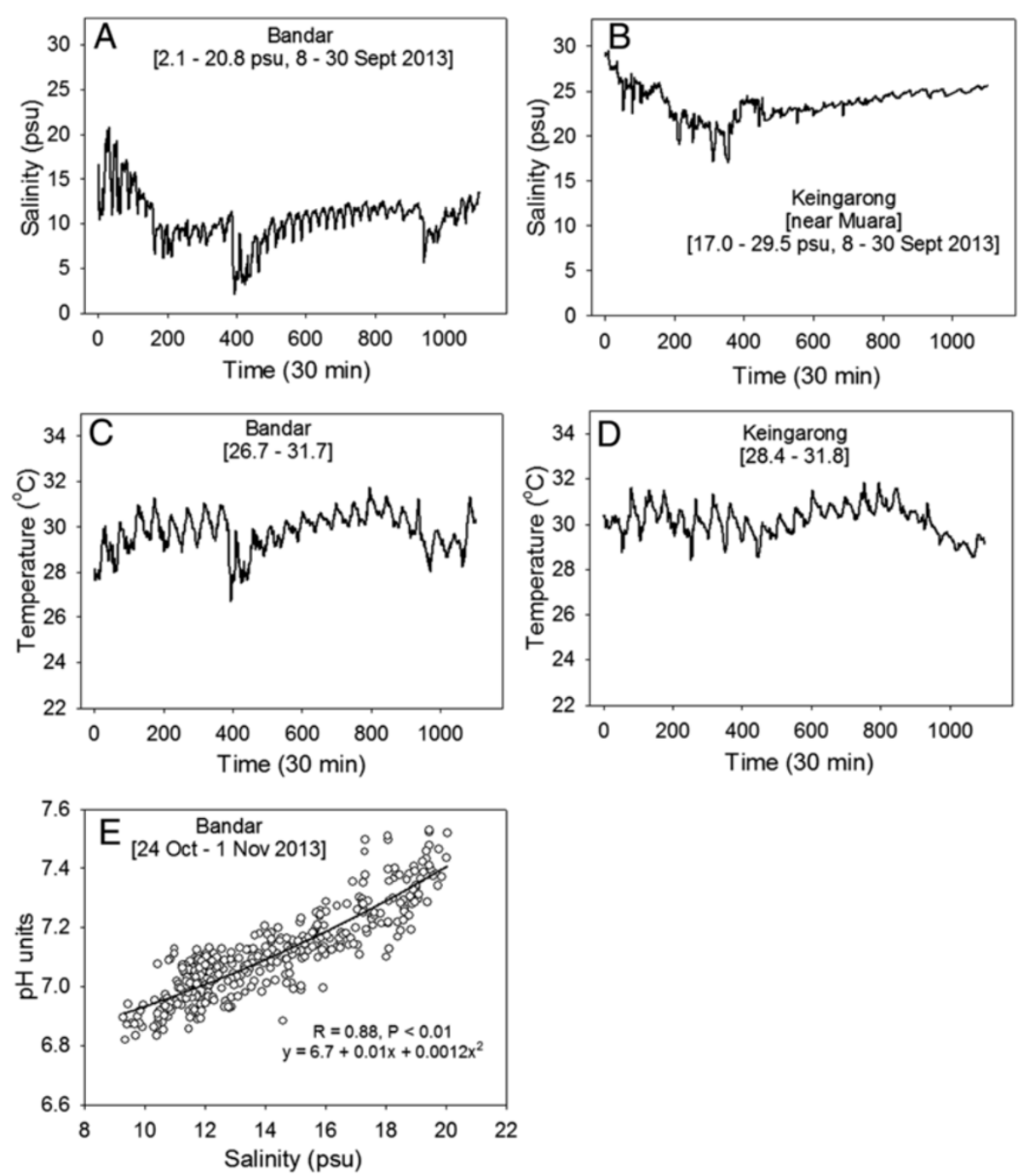

Figure 2 High resolution salinity and temperature data for the BES estuarine water. A-D) Recordings were made every 30 min, between 8 and 30 September 2013, simultaneously at Bandar and Keingarong (near Muara). Variations in diurnal (tidal) and longer-term measurements of salinity were greater at Bandar compared to Keingaron, and the salinity regime at Keingaron was distinctly higher. Temperature varied in a similar way at each site. E) The relationship between $\mathrm{pH}$ and salinity for simultaneous recordings (every $30 \mathrm{~min}$ ) for just under 1 week (24 October to 1 November 2013).

calculated rarefaction curves for the six samples leveled off from the 1:1 interval but were far off from reaching an asymptote (Figure 4). The estimated richness declined to almost half of the highest estimates towards the marine sites (Table 2). The micro-diversity at $100 \%$ OTU cut-off revealed the highest richness in the Sungai Besar samples with 2883 estimated OTU's (data not shown). The Shannon diversity index calculated at a 97\% cut-off value varied between $\mathrm{H}=3.1$ and $\mathrm{H}=3.9$ with the highest diversity found in the Bengkurong mudflat samples and the lowest in Bandar and Damuan.

Comparison of the obtained sequences with the Silva databases revealed that for all samples most sequences only have a high identity (average of $98.3 \%$ identity) with uncultivated species from the Silva SSU NR ref database
(Figure 5A). The average identity of all sequences with the SSU database of cultivated species is $94.7 \%$. The lowest identity for a sequence read was found in Bandar, this DNA sequence revealed $75.8 \%$ identity with a sequence from the SSU database of cultivated species and $96.7 \%$ identity with a sequence clone designated as belonging to Candidate divisions BD1-5 and more particularly with a strain identified in hypersaline microbial mats in Guerrero Negro [34]. Further analysis of the identities showed that a large fraction (average of 56.7\%) of the sequenced clones was derived from species with less than $97 \%$ identity to known isolated species and $17.2 \%$ of the sequences had less than $97 \%$ identity with all known sequences in the Silva database. Most novel species were found in Bengkurong and Sungai Besar; 


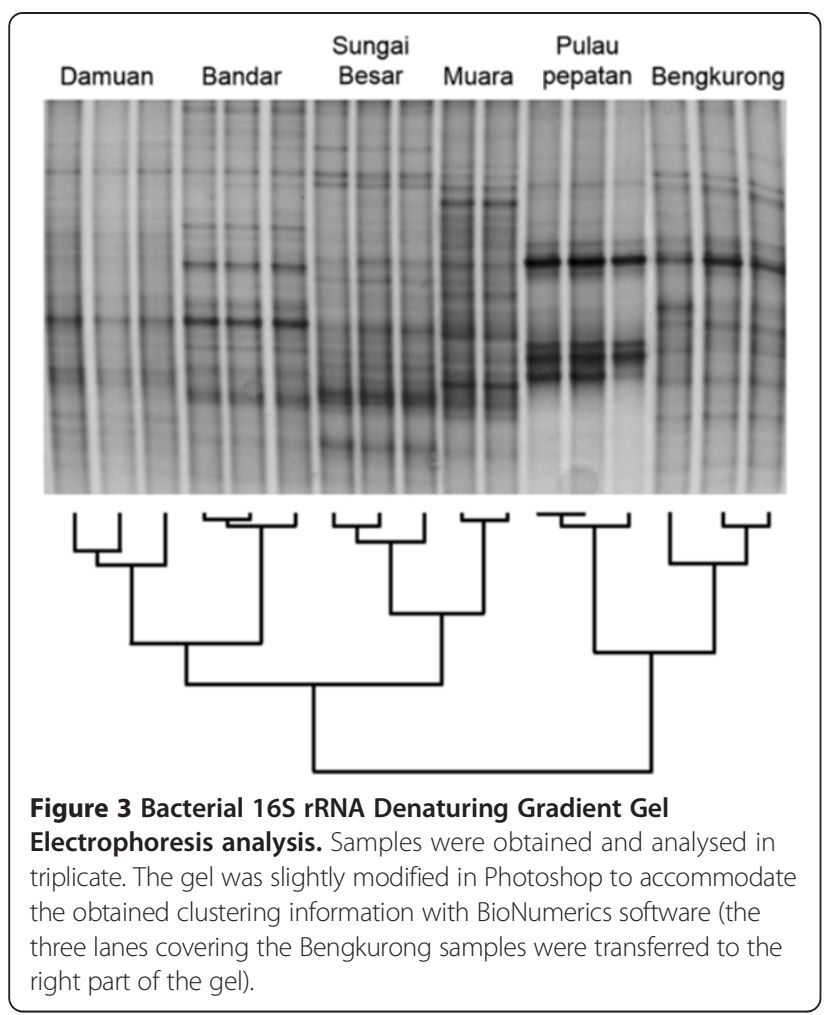

respectively $69 \%$ and $68 \%$ of the clones had less than $97 \%$ identity with the best match in the SSU database versus $18 \%$ and $22 \%$ with the SSU NR database (Figure $5 \mathrm{~B}$ ). Comparison of the shared number of OTU's between the samples from different locations using the "summary. shared" command in Mothur revealed that at a cut-off level of $97 \%$ on average $90 \%$ of the OTU's in pooled samples from each location is unique to that site (data not shown). The highest number of overlapping sequences with $97 \%$ or more identity between two locations was only 6 for Muara and Sungai Besar.

Taxonomic annotation of the $16 \mathrm{~S}$ rRNA sequences showed that Proteobacteria and chloroplasts derived from diatoms form the dominant groups in the Brunei mudflats taking up more than $60 \%$ of the total diversity. Chloroplast sequences form the majority in Bandar (53.7\%), Damuan (50.9\%) and Muara (40.5\%) and form the second largest group in Sungai Besar (30.8\%), Bengkurong

Table 2 Diversity and richness indices at $97 \%$ cut off value

\begin{tabular}{lllll}
\hline Sample & \# clones & Sobs $^{\mathbf{a}}$ & Chao & Shannon (H) \\
\hline Bengkurong & 106 & 72 & 351 & 3.9 \\
Damuan & 134 & 54 & 430 & 3.1 \\
Bandar & 116 & 51 & 192 & 3.1 \\
Sungai Besar & 116 & 82 & 193 & 3.7 \\
Muara & 133 & 63 & 231 & 3.6 \\
Pulau Pepatan & 142 & 79 & 237 & 3.8 \\
\hline
\end{tabular}

a Observed OTU's.
(25\%) and Pulau Pepatan (16.8\%). With 51\%, 43.6\% and $40.5 \%$ of the total sequences, Proteobacteria dominate the populations in Pulau Pepatan, Sungai Besar and Bengkurong respectively (Figure 6A). These two groups were followed in order of abundance by Bacteroidetes (on average 11\%), Cyanobacteria (4\%), Acidobacteria (4\%), Planctomycetes $(\sim 2 \%)$ and Actinobacteria (1\%). The diversity is further followed by a number of species with only one or two representatives in the clone libraries. Amongst these are a number of sequences derived from candidate divisions several of which still lacking cultivated representatives. These candidate division related sequences are often confined to one or two samples.

Further dissection of the proteobacterial phylum revealed that Delta- and Gammaproteobacteria formed the dominant groups making up $80-90 \%$ of the Proteobacteria and with a trend of more Deltaproteobacteria in the freshwater sites and more Gammaproteobacteria in the marine sites (Figure 6B). Alphaproteobacteria are found in each site at approximately $10 \%$ of the total proteobacterial fraction. Beta- and Epsilonproteobacteria are present in some samples and only at low abundance.

Cluster analysis of the phylogenetic distribution within the samples show clustering of the freshwater sites Bandar and Damuan and of the marine sites. The most upstream located freshwater site Bengkurong clusters with the marine outlier site Pulau Pepatan (Figure 7A). Clustering of the proteobacterial classes gave a clear distinction between the marine and freshwater communities (Figure 7B).

\section{Discussion}

The Brunei River and Bay estuarine system forms a unique tropical ecosystem that has not yet been the subject of microbial diversity studies. The nearly continuous input of acidic, sediment-rich freshwater in the Brunei Bay provides a unique opportunity to study consequences of acidification and eutrophication on marine ecosystems. For example, Marshall and co-workers showed that acid input from the Brunei River led to a dramatic erosion of gastropod shells [25]. The microbial study presented here focuses on the mudflats along the Brunei River into the bay. Since mudflat sediments are quite stable with respect to $\mathrm{pH}$ homeostasis we did not directly expect nor look for changes related to $\mathrm{pH}$ but rather focussed on the increased salinity from river to sea. While the column water salinity and $\mathrm{pH}$ of the BES were strongly correlated (Figure 2; [25]), preliminary assessments suggest relatively invariable $\mathrm{pH}$ in BES sediments (unpublished observations; Hossain, PhD thesis). Salinity is of special interest since it is a well-known driver for microbial diversity and in contrast to $\mathrm{pH}$ cannot be regulated by microbial activity [35].

The first noteworthy observation when looking at the OTU statistics is the very low identity with known 


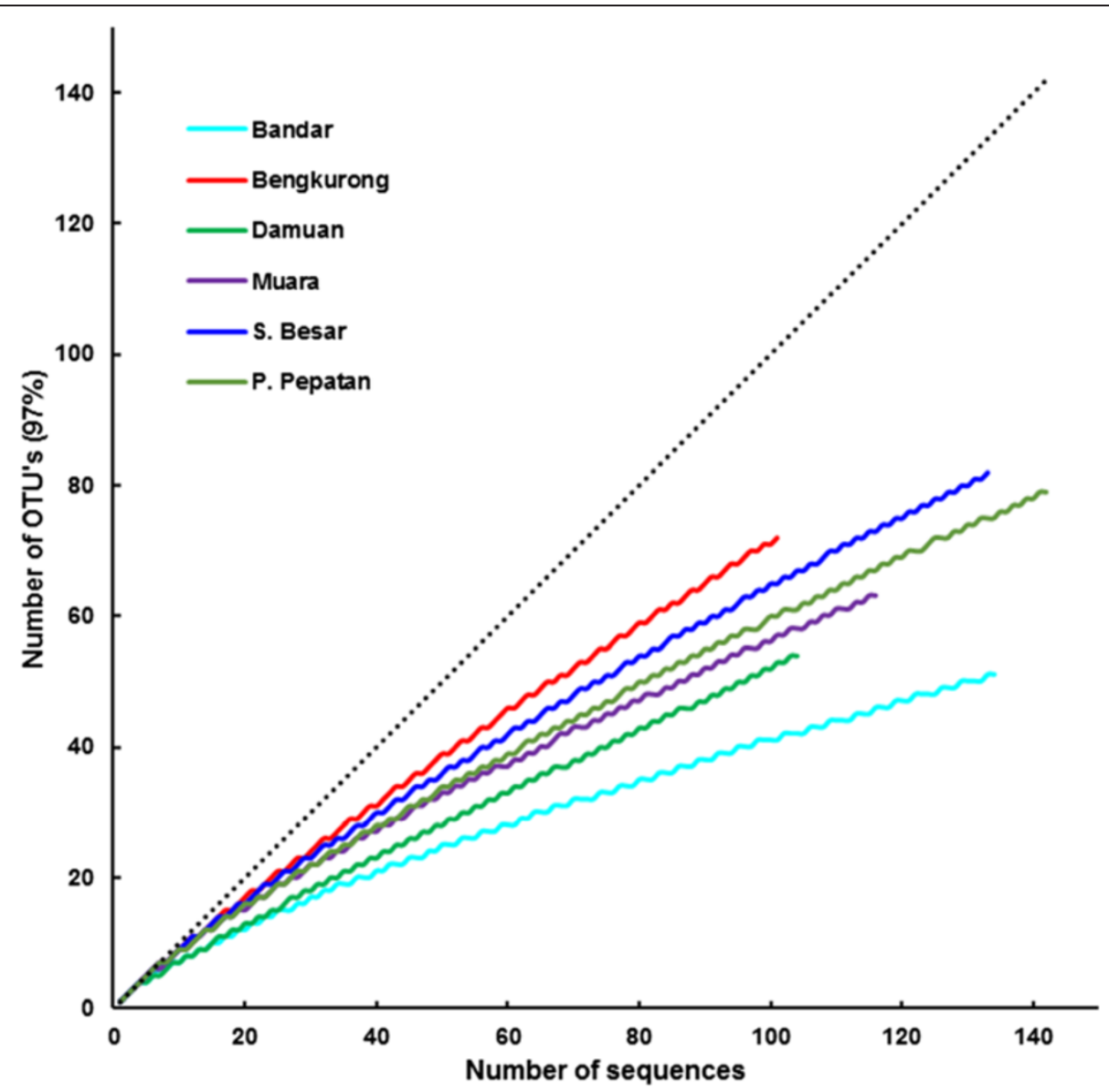

Figure 4 Rarefaction analysis of the OTU's of the six samples at $\mathbf{9 7 \%}$ sequence identity. The dotted line indicates the 1:1 line.

cultivated bacterial species. The fact that almost $60 \%$ of the sequences in our clone library have less than 97\% identity with known species shows that the Brunei mudflats harbour a unique undiscovered microbial ecosystem. Bengkurong and Sungai Besar harbour the most novel species, even when compared to sequences obtained by cultivation independent studies that reveal about $20 \%$ with less than $97 \%$ identity. This is also reflected in the taxonomic identification revealing that 11 out of the 28 identified phyla belong to candidate divisions (BRC1, WS3, TA06, BD1-5, BHI80-139, OP11, OP8, JL-ETNPZ39,NPL-UPA2, RF3, TM6), most of which still have no cultivated representatives. Although these candidate divisions are only represented by low numbers of sequences in our data set, they still make up $1-2 \%$ of the total community and should be considered as abundant rather than rare. Obviously high throughput sequencing will provide a better insight in the true rare microbial diversity [36-38] and is planned for a follow-up analysis on this ecosystem. Even at a lower taxonomic level (order, genus, family), several novel "candidate" taxa are found including species with a yet uncertain taxonomic placement (Class Incertae Sedis). For example, amongst the Bacteroidetes we found representatives of group BD2-2, SB-1 and vadinHA17. Most of these candidate divisions and 'uncertain' groups are currently identified in a wide and diverse variety of environments making a potential link to ecosystem functioning impossible until members of these groups are isolated and characterized or until full genomic information is available. Despite the large number of novel species, the Shannon diversity and Chao richness estimators are comparable to similar studies of mudflat microbial diversity in estuaries world-wide $[39,40]$. We have to keep in mind that the rarefaction curves show that with $\sim 110-135$ clones the mudflats are under-sampled and that the actual richness and diversity are likely higher than estimated here especially since the Chao index is known to underestimate true richness at low sample sizes [41]. A more definite conclusion will require next generation sequencing approaches $[37,38]$.

The major functional groups identified in this study and their relative contributions are common to many mudflat ecosystems $[42,43]$. The systems are driven by photosynthetic primary producers and there is an obvious important role for bacteria involved in sulfur cycling. Primary production is dominated by diatoms, whereas 


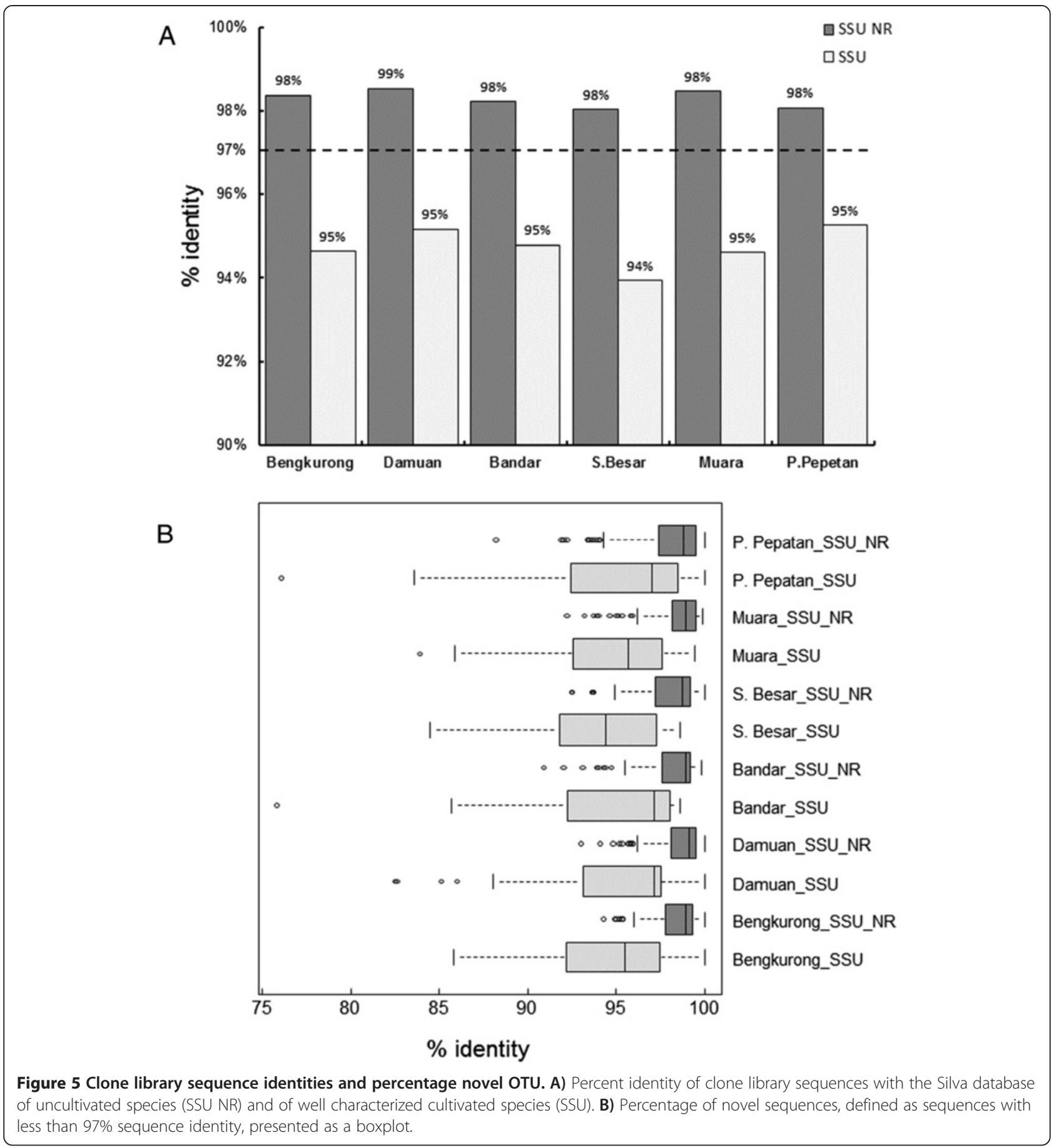

Cyanobacteria only play a minor role, given their low abundance. This is in agreement with the general prevalence of diatoms for fine grained muddy sediments, whereas Cyanobacteria favour sandy, course grained sediments [44]. Proteobacteria are the dominant players in sulfur cycling with sulfate reducing Deltaproteobacteria and sulfide oxidizing Gammaproteobacteria. Amongst the Deltaproteobacteria the sulfate reducers Desulfobacteraceae and Desulfobulbaceae dominate the population. Desulfobulbaceae are found in all sites while Desulfobacteraceae are absent from Damuan (with one exception) and Bandar. Apparently, the Desulfobacteraceae prefer the more saline mudflats and the mudflat from the most acidic region of the river in Bengkurong. Potentially there is a relationship with the presence of Desulfobacteraceae and the somewhat more extreme character of these mats relative to the Bandar and Damuan sites or alternatively, this class of organisms is more sensitive to the high anthropogenic 


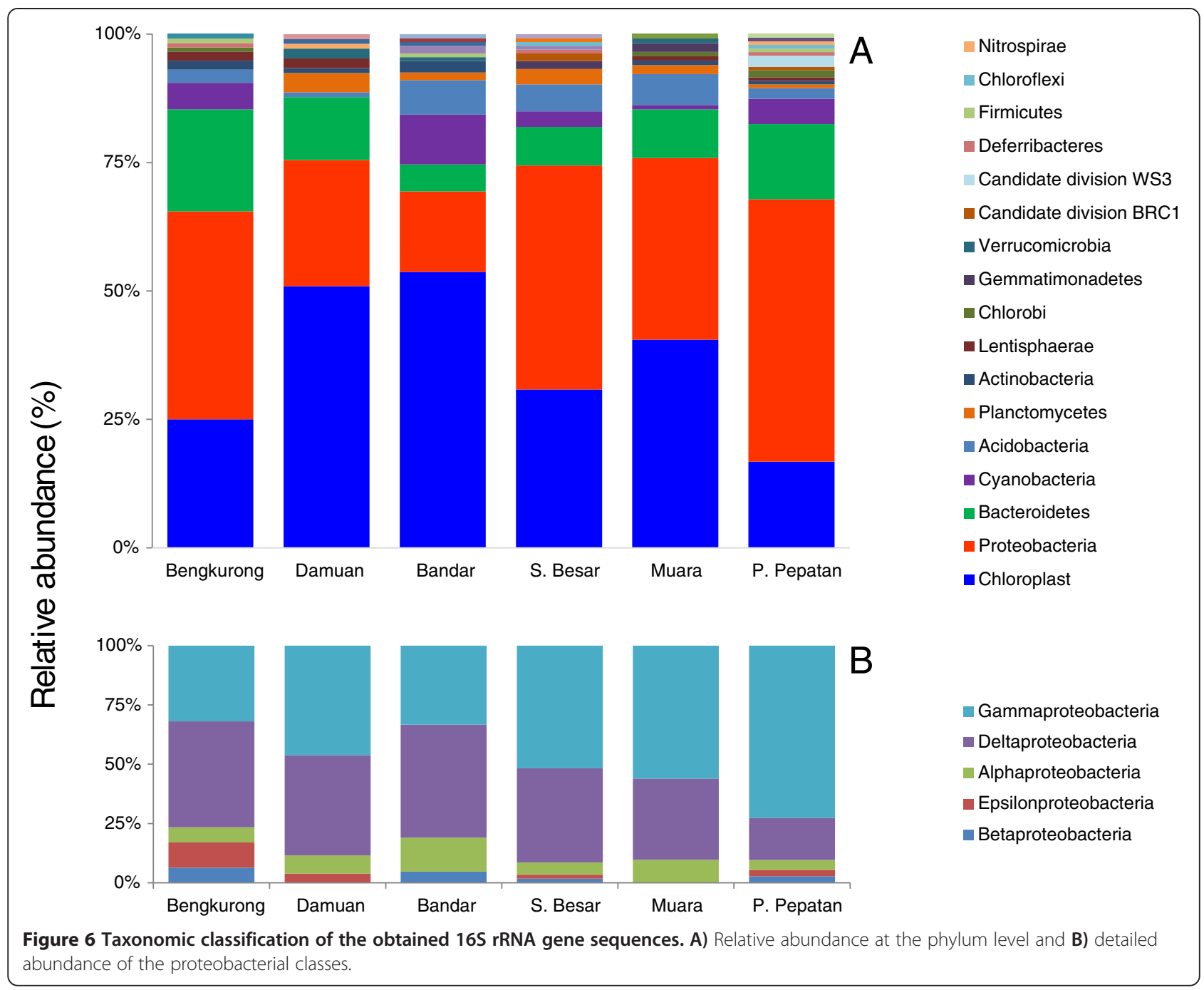

carbon load and eutrophication at these two sites. Other potential sulfur (but not sulfate) reducing species were found amongst the Epsilonproteobacteria and mostly in Bengkurong (Sulfurovum and Sulfurimonas). Sulfide oxidizing species were found amongst the Gammaproteobacteria, the most dominant bacterial class in all samples. These sulfide oxidizers belong to the Chromatiales, Thiotrichales and

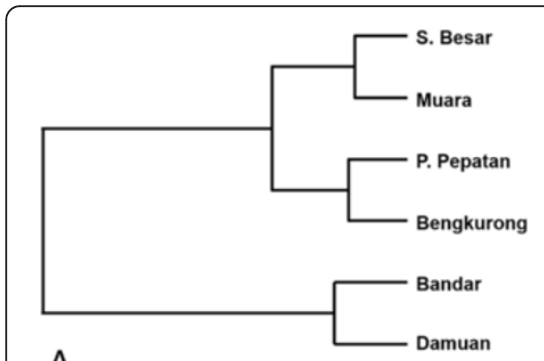

A

Figure 7 Cluster analysis of the phyla A) and proteobacterial class B) distribution in the six samples. yet unclassified taxa with representatives Thiohalophilus, a typical marine sulfide oxidizing bacterium and Candidatus Thiobios, a symbiotic sulfide oxidizing organism that is found in symbiosis with marine ciliates [45]. Other members of the Gammaproteobacteria found in the Brunei mudflats have a heterotrophic lifestyle and are represented by the Xanthomonadales (mainly consisting of the uncultivated marine benthic group in the marine sites), Alteromonadales and Vibrionales, a large number of which are assigned as Photobacterium related species, typical marine species that are abundant in Pulau Pepatan. Representatives of the green sulfur bacteria, Chlorobi, are found in very low numbers, a single sequence in Bengkurong and Muara and 2 sequences in Pulau Pepatan. All four sequences were related to the anaerobic genus of Ignavibacteria. Alphaproteobacteria were found in all sites and mainly consist of the phototrophic bacteria belonging to the Rhodobacterales. Although initially believed not to oxidize sulfur, several Rhodobacterales species were shown to oxidize sulfur, sulfide or thiosulfate [46]. Bacteroidetes related species are found in high numbers in 
each sampled mudflat and are represented by the versatile heterotrophic members of the orders Cytophagales, Flavobacteriales and Sphingobacteriales that are involved in the degradation of a wide variety of complex organic compounds.

Cluster analysis of the phyla distribution as well as of the DGGE fingerprints gave a somewhat surprising result in that the mudflat at Bengkurong, which is exposed to acidic freshwater, appeared more similar to the marine and higher $\mathrm{pH}$ outlier mudflat of Pulau Pepatan. This result was independent of whether the chloroplast fraction was present or absent from the cluster analysis dataset. However, when looking at the proteobacterial fraction only, a clear distinction became visible between the three freshwater sites and the three marine sites. Potentially the conditions upstream of the Brunei River favour a lower contribution of diatoms and a larger contribution of Proteobacteria and Bacteroidetes similar to that on Pulau Pepatan. The cause of these effects cannot be determined at this moment, but requires an in depth study of the geochemical and microbial composition of the mudflats.

BES is situated within the biodiversity hotspot associated with the shallow South East Asian Sunda shelf that was above the sea level for much of the Quaternary glacial periods, Sundaland $[47,48]$. High biodiversity in this region is evident [49-51], but what drives this diversity is not well understood. One hypothesis for the high biodiversity in tropical regions in general, considers the potentially greater "effective" evolutionary time (evolutionary speed) as the result of shorter generation times, faster mutation rates, and faster selection at relatively stable and higher temperatures [52]. Distance decay as well as environmental factors appear important drivers of for example the diversity of nitrifying bacteria in salt marshes in temperate marshes as they also are for plants and animals [53]; these appear also important drivers in deep-sea bacterial communities in the china sea [54]. Analyses of literature further confirms that although present day environment are predominant drivers for bacterial communities, the historical component is always also present suggesting that bacterial communities like animals and plants are also determined by dispersal strategies and of similar distance decay [55]. Halfbeaks, freshwater fishes from Borneo, illustrate the geological evolution of diversity in Borneo: halfbeaks sampled from adjacent drainage basins but representing distinct paleo-drainages were phylogenetically dissimilar to one another, but were similar to halfbeaks from the same paleo-drainage on separate landmasses suggesting that geological drivers were important to seed landmasses such as the Malay Peninsula and Borneo before the Quaternary [56]. The mitochondrial DNA tree of the halfbeak genus Dermogenys is further consistent with radiation and speciation during the Quaternary, possibly before the last glacial cycle [56]. Yet geological history may be just one of many drivers leading to environmental heterogeneity which was demonstrated as a universal driver of species richness [57]. The uniqueness of the microbiome, as presented here for the BES, and previously shown for Sarawak forest soils [58], may be a key unexplored factor contributing to the botanical richness and species endemicity of Bornean environments [59].

\section{Conclusion}

The Brunei River and Estuarine System harbours a unique microbial habitat with a high diversity of novel species that are of potential interest for metabolic and biotechnological exploration. Not only are the obtained sequences unique in comparison to other mudflats around the world, but there is also little overlap between individual site, with less than $10 \%$ of the sequences having more than $97 \%$ identity to known sequences in the Silva database. Despite this overwhelming number of novel species, the functional composition of these mudflats is well conserved in comparison to other mudflats. Given the extreme $\mathrm{pH}$ gradient over the river-estuary trajectory we expect more exciting discoveries in the water samples that are less stable than the sediment samples.

\section{Methods}

\section{Sample sites and sampling}

The Brunei River (Sungai Brunei, approximately $40 \mathrm{~km}$ long) is the shortest of three large river systems, including the Limbang and Temburong rivers, that feed into the estuarine system of the Inner Brunei Bay (IBB,

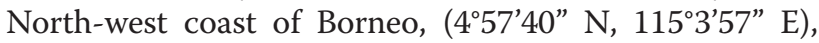
see Figure 1). The catchment area of the IBB is extensive $\left(380 \mathrm{~km}^{2}\right)$ and during fairly rare regional flooding (decadal), these rivers contribute to massive freshwater flux and carry high silt loads. Salinity and $\mathrm{pH}$ regimes along the BES are diurnally tidally-dominated by seawater fluxes, though during monsoon periods regular (daily) downpours shift these regimes along the BES and flatten their gradients $[25,60]$. Previously measured salinities vary between 0 and $34 \mathrm{psu}$, and $\mathrm{pH}$ varied between 5.7 and 8.4 units [25].

Sampling was undertaken along the length of the BES at six sites, from landward to seaward, as follows: Bengkurong, Damuan, Bandar, Sungai Besar, Muara, and Pulau Pepatan (Figure 1). Sampling coordinates are listed in Table 1. The mudflats around Pulau Pepatan (Pepatan Island), a mangrove covered island in the Brunei Bay that is not directly in the stream of the Sungai Brunei was chosen as an out-group.

Given diurnal tidal forcing and stochastically variable freshwater inflow, the frequency of exposure to estuarine water of high salinity/pH (which increases seaward) and 
of low salinity/pH (which increases landward) differs among the sites. Figure 2 shows the temporal variation in salinity and $\mathrm{pH}$ in the water at dedicated stations, Bandar (landward) and Keingarong, near Muara (extreme seaward). Salinity recordings were logged every $30 \mathrm{~min}$ between 8 and 30 Sept 2013, and both $\mathrm{pH}$ and salinity were recorded between 24 Oct and 01 Nov 2013, using HOBO conductivity data loggers (U25-001, Onset, Massachusetts, USA) and a WQL-pH logger (WTW GmbH, Germany). On site salinity and $\mathrm{pH}$ could not be accurately measured in the sediment, so were measured in the water flowing at approximately 1 meter from the sampling point; salinity was measured to \pm 0.01 psu (YSI Model $85 \mathrm{D}$ multimeter or $\mathrm{HACH} \mathrm{HQ} 40 \mathrm{~d}$ meter and IntelliCal probe) and $\mathrm{pH}$ to \pm 0.01 units using an NBS scale (Thermo Orion Model 260A or HACH HQ40d calibrated with Mettler Toledo SRM NIST precision buffers). Additionally, the microbial communities at all of the sites are exposed to variation in pore-water $\mathrm{pH}$ in the sediments, which could counteract fluctuations in estuarine water $\mathrm{pH}$ (Hossain, unpublished data). Sample sites further differed in degree of siltation and organic loads. Anthropogenic and natural organic inputs are greatest around Damuan, and especially Bandar, via the Kedayang tributary (Marshall et al. 2008), which leads from the commercial centre of Brunei (Gadong and Kuilap). Although fringing mangroves along most of the Brunei River contribute natural organic material, treated and untreated sewerage is released near Bandar (Kampong Ayer and Pintu Malim, respectively). The sediment surfaces at Sungai Besar and Muara are inundated by increasing clearer, high saline waters, and are assumed less eutrophic. Furthermore, though the sand-size fraction of the sediments is generally higher at the seaward sites and finergrained sediments (and a concomitant greater organic matter portion) are found landwards, sediment granulometry in the estuarine system is patchy [60].

Sampling was performed during the wet season on November $4^{\text {th }}, 2012$. Samples were taken at low tide when all mudflats were exposed to air and accessible. Samples were taken in triplicates using a sterile syringe corer, of which the top was removed. Approximately $10 \mathrm{~mm}$ of the top sediment layer was immediately mixed in lysis buffer containing tubes provided by the Ultra-clean DNA isolation kit (MO-BIO Laboratories, Inc., Carlsbad, CA, USA). Samples were initially stored at $4^{\circ} \mathrm{C}$ for a maximum of 3 hours and subsequently frozen at $-20^{\circ} \mathrm{C}$ until nucleic acid extraction.

\section{Nucleic acid extraction}

Total community DNA was isolated from approximately $1 \mathrm{~g}$ (wet weight) of sediment using the MOBIO UltraClean Soil DNA Isolation Kit according to the manufacturer's protocol for maximum yield. DNA concentrations were measured spectrophotometrically using the NanoDrop ${ }^{\mathrm{TM}}$ ND-1000 spectrophotometer (NanoDrop products, Wilmington, DE, USA). For controlled and reproducible downstream analysis the DNA concentration for each sample was adjusted to $15 \mathrm{ng} / \mu \mathrm{l}$ by adding diethylpyrocarbonate treated water.

\section{Ribosomal RNA gene amplification and sequencing}

Bacterial 16S rRNA gene fragments were amplified from each sample by polymerase chain reaction (PCR) using the bacterial specific primers B8f (AGAGTTTGATCM TGGCTCAG) [61] and the universal primer U1492r (GGTTACCTTGTTACGACTT) [62]. A $50 \mu \mathrm{l}$ of PCR mixture consisted of $200 \mu \mathrm{M}$ of dNTPs (Roche Applied Science), $200 \mathrm{nM}$ of each primer, $5 \% \mathrm{v} / \mathrm{v}$ of dimethyl sulfoxide (Sigma-Aldrich), $0.1 \% \mathrm{w} / \mathrm{v}$ of bovine serum albumin (Fermentas). 2 units of Hot Star Taq DNA polymerase (Qiagen Inc.) and $1 \mu$ template. The reactions were run on a thermal cycler (Thermal Cycler 2720, Applied Biosystem) using the following PCR conditions: $15 \mathrm{~min}$ at $95^{\circ} \mathrm{C}$; 35 cycles of $60 \mathrm{~s}$ at $95^{\circ} \mathrm{C}$, $30 \mathrm{~s}$ at $53^{\circ}, 120 \mathrm{~s}$ at $72^{\circ} \mathrm{C}$ and a final extension step for $7 \mathrm{~min}$ at $72^{\circ} \mathrm{C}$. Amplicon sizes were verified by agarose gel electrophoresis. Amplicons of the desired size and concentration were purified on E.Z.N.A. Cycle Pure columns (Omega Bio-Tek Inc.) and cloned using the TOPO-TA cloning Kit (Invitrogen Corp.) following the manufacturer's instructions. Positive transformants were identified by colony PCR using the M13 forward and reverse vector primers to amplify the inserted gene fragments. Amplicons containing insert DNA of the appropriate size were purified using Sephadex G-50 Superfine (Sigma-Aldrich) and DNA concentrations were determined spectrophotometrically. Amplicons were sequenced using the BigDye Terminator chemistry (Big Dye Terminator v3.1 Cycle Sequencing Kit, Applied Biosystem) according to the manufacturer's instructions. The sequencing primer used was U1492r.

\section{Denaturing Gradient Gel Electrophoresis (DGGE)}

Bacterial 16S rRNA gene specific DGGE-PCR reaction was performed using the following conditions. The PCR reaction mix contained per $25 \mu \mathrm{l}$ of PCR mixture, $200 \mu \mathrm{M}$ of dNTPs, $200 \mathrm{nM}$ of each primer, $3 \% \mathrm{v} / \mathrm{v}$ of dimethyl sulfoxide, and 1 units of Taq DNA polymerase (GE Healthcare). The primers used were the universal U1492R primer and F968-GC (CGCCCGGGGCGCGCC CCGGGCGGGGCGGGGGCACGGGGGGCCTACGGGA GGCAGCAG) [63]. The PCR conditions were as following: initial denaturation for 3 minutes at $95^{\circ} \mathrm{C}, 10$ cycles with denaturation for $60 \mathrm{~s}$ at $95^{\circ} \mathrm{C}$, annealing for $60 \mathrm{~s}$ at $60^{\circ} \mathrm{C} / 55^{\circ} \mathrm{C}$ (touch down with a $1^{\circ} \mathrm{C}$ decline per cycle) and an extension $120 \mathrm{~s}$ at $72^{\circ} \mathrm{C}$, followed by 25 cycles of denaturation for $60 \mathrm{~s}$ at $95^{\circ} \mathrm{C}$, annealing for $60 \mathrm{~s}$ at $55^{\circ} \mathrm{C}$, 
extension for $120 \mathrm{~s}$ at $72^{\circ} \mathrm{C}$ and an final extension for 30 minutes at $72^{\circ} \mathrm{C}$. Reaction mixtures were purified using E.Z.N.A. Cycle Pure columns. After purification, the DNA concentration in each sample was determined spectrophotometrically and adjusted to a final concentration of $200 \mathrm{ng}$ of DNA in $28 \mu \mathrm{l}$, supplemented with $2 \mu \mathrm{l}$ of loading buffer [64] and applied on the DGGE gel. The DGGE gel was run on the IngenyphorU $U^{\circ}$ system (Ingeny International). A denaturing polyacrylamide gel ( $8 \% \mathrm{w} / \mathrm{v}$ acrylamide) was made according to the DGGE system manufacturer's instructions using the gradient maker provided by the manufacturer in order to generate a urea-formamide gradient. The gradients ranged from $50-70 \% \mathrm{v} / \mathrm{v}$. To $24 \mathrm{ml}$ of the acrylamide-urea-formamide solution $50 \mu \mathrm{l} 20 \% \mathrm{w} / \mathrm{v}$ ammonium-persulfate and $5 \mu \mathrm{l}$ of tetramethylethylenediamine were added to initiate polymerization. The stacking gel consisting of $8 \% \mathrm{w} / \mathrm{v}$ acrylamide but lacking the denaturants was poured on top of the gel. Samples and reference samples were subjected to electrophoresis at $100 \mathrm{~V}$ for $18 \mathrm{~h}$ in a 0.5 strength TEA buffer at $60^{\circ} \mathrm{C}$. After electrophoresis, DGGE gels were silver stained using an automated gel stainer (Hoefer Processor Plus, Amersham Biosciences). The following staining protocol was used; Gel fixation was achieved by soaking the gel for $30 \mathrm{~min}$ in a solution of $0.05 \% \mathrm{v} / \mathrm{v}$ acetic acid and $10 \% \mathrm{v} / \mathrm{v}$ ethanol. Gel staining was performed in a $0.2 \% \mathrm{w} / \mathrm{v}$ silver nitrate solution for $15 \mathrm{~min}$, followed by three 1 min washing steps with Milli-Q water. After washing, the gels were processed for $5 \mathrm{~min}$ with a developing solution consisting of $1.5 \% \mathrm{w} / \mathrm{v}$ sodium hydroxide and $0.15 \% \mathrm{v} / \mathrm{v}$ formaldehyde. Finally, gels were soaked in $0.75 \% \mathrm{w} / \mathrm{v}$ sodium carbonate for $5 \mathrm{~min}$ to stop the developing and conserved by adding $10 \% \mathrm{v} / \mathrm{v}$ glycerine in $25 \% \mathrm{v} / \mathrm{v}$ ethanol and incubated for $7 \mathrm{~min}$. For each step, $200 \mathrm{ml}$ of the according solutions was used.

\section{Community fingerprint analysis}

The DGGE fingerprints were analysed using the BioNumerics software package (Applied Maths NV, Sint-MartensLatem, Belgium). Fingerprints were normalized, subjected to the curve based Pearson correlation method to create the similarity index and clustered using the UPGMA algorithm.

\section{DNA sequence and phylogenetic analysis}

Geneious software (Geneious version (R6: 6.1.8) created by Biomatters. Available from http://www.geneious.com) was used to analyse and correct the ABI trace files and to conduct phylogenetic analysis. 16S rRNA Sequences were compared to two different databases in an offline Blast integrated in the Geneious software. The SILVA SSU Ref database is a cured database of $16 \mathrm{~S}$ rRNA sequences obtained from isolated species with a minimal length of 1200 bases [65]. The non-redundant version of the SILVA SSU Ref database (Silva SSU ref NR) contains sequences derived from isolated species but also from a large number of uncultivated species obtained via environmental studies. The best blast hits were used for phylogenetic annotation at several taxonomic levels. General statistics on operational taxonomic units (OTU's) and estimation of richness and diversity were performed on the collected fasta files using the molecular analysis software package Mothur [66]. The sequences were checked for potential chimeric sequences using the online chimera check tool Decipher (http://decipher.cee.wisc.edu/FindChimerasOutputs.html). Suspected chimera were manually checked and removed if required.

DNA sequences described in this study were deposited in GenBank with the accession numbers KJ941391 - KJ942135.

\section{Competing interests}

The authors declare that they have no competing interests.

\section{Authors' contributions}

$\mathrm{HB}, \mathrm{HS}$ and DJM were involved in the field work campaign. Molecular analysis was carried out by HB, HS and JK. All authors were involved in drafting the manuscript. All authors read and approved the final manuscript.

\section{Acknowledgements}

We thank Sorya Proum for help in the field and for the provision of preliminary salinity data. This study was funded through a Universiti Brunei Darussalam grant (UBD/GSR/S\&T/16)

\section{Author details}

${ }^{1}$ Department of Marine Microbiology, Royal Netherlands Institute of Sea Research (NIOZ), P.O. Box 140, 4400AC Yerseke, The Netherlands. ${ }^{2}$ Molecular Plant Physiology, Utrecht University, Padualaan 8, 3584CH Utrecht, The Netherlands. ${ }^{3}$ Environmental and Life Sciences, Faculty of Science, Universiti Brunei Darussalam, Tungku Link, Gadong BE1410, Brunei Darussalam. ${ }^{4}$ Institut Teknologi Brunei, Tungku Link, Gadong BE1410, Brunei Darussalam.

Received: 20 June 2014 Accepted: 19 October 2014

Published: 30 October 2014

\section{References}

1. Underwood GJC, Kromkamp J: Primary production by phytoplankton and microphytobenthos in estuaries. Adv Ecol Res 1999, 29:93-153.

2. de Winder B, Staats N, Stal LJ, Paterson DM: Carbohydrate secretion by phototrophic communities in tidal sediments. J Sea Res 1999, 42:131-146.

3. Paterson DM: Short-term changes in the erodibility of intertidal cohesive sediments related to the migratory behavior of epipelic diatoms. Limnol Oceanogr 1989, 34:223-234.

4. Passarelli C, Olivier F, Paterson DM, Meziane T, Hubas C: Organisms as cooperative ecosystem engineers in intertidal flats. J Sea Res 2013, 92:92-101.

5. Jorgensen BB: Mineralization of organic-matter in the sea bed - the role of sulfate reduction. Nature 1982, 296:643-645.

6. Leloup J, Quillet L, Berthe T, Petit F: Diversity of the dsrAB (dissimilatory sulfite reductase) gene sequences retrieved from two contrasting mudflats of the Seine estuary, France. FEMS Microbiol Ecol 2006, 55:230-238.

7. Visscher PT, Gritzer RF, Leadbetter ER: Low-molecular-weight sulfonates, a major substrate for sulfate reducers in marine microbial mats. Appl Environ Microbiol 1999, 65:3272-3278.

8. Cappenberg TE, Prins RA: Interrelations between sulfate-reducing and methane-producing bacteria in bottom deposits of a fresh-water lake. III. experiments with 14C-labeled substrates. Antonie Van Leeuwenhoek 1974, 40:457-469.

9. Widdel F, Pfennig N: A new anaerobic, sporing, acetate-oxidizing, sulfate-reducing bacterium, Desulfotomaculum (emend.) acetoxidans. Arch Microbiol 1977, 112:119-122.

10. Barton LL, Tomei FA: Characteristics and activities of sulfate-reducing bacteria. In Sulfate-Reducing Bacteria, Biotechnology Handbooks. 8th edition. Edited by Barton LL. New York, US: Springer; 1995:1-32. 
11. Coulon F, Chronopoulou PM, Fahy A, Paisse S, Goni-Urriza M, Peperzak L, Acuna Alvarez L, McKew BA, Brussaard CP, Underwood GJ, Timmis KN, Duran R, McGenity TJ: Central role of dynamic tidal biofilms dominated by aerobic hydrocarbonoclastic bacteria and diatoms in the biodegradation of hydrocarbons in coastal mudflats. Appl Environ Microbiol 2012, 78:3638-3648.

12. Leloup J, Petit F, Boust D, Deloffre J, Bally G, Clarisse O, Quillet L: Dynamics of sulfate-reducing microorganisms (dsrAB genes) in two contrasting mudflats of the Seine estuary (France). Microb Ecol 2005, 50:307-314.

13. Mayor DJ, Thornton B, Zuur AF: Resource quantity affects benthic microbial community structure and growth efficiency in a temperate intertidal mudflat. PLoS One 2012, 7:e38582

14. Roling WF, Milner MG, Jones DM, Fratepietro F, Swannell RP, Daniel F, Head IM: Bacterial community dynamics and hydrocarbon degradation during a field-scale evaluation of bioremediation on a mudflat beach contaminated with buried oil. Appl Environ Microbiol 2004, 70:2603-2613.

15. Jiang XT, Peng X, Deng GH, Sheng HF, Wang Y, Zhou HW, Tam NF: Illumina sequencing of $16 \mathrm{~S}$ rRNA tag revealed spatial variations of bacterial communities in a mangrove wetland. Microb Ecol 2013, 66:96-104.

16. Lee J, Lee TK, Loffler FE, Park J: Characterization of microbial community structure and population dynamics of tetrachloroethene-dechlorinating tidal mudflat communities. Biodegradation 2011, 22:687-698.

17. Dent $\mathrm{DL}$, Pons LJ: A world perspective on acid sulphate soils. Geoderma 1995, 67:263-276.

18. Grealish G, Fitzpatrick R: Acid sulphate soil characterization in Negara Brunei Darussalam: a case study to inform management decisions. Soil Use Manage 2013, 29:432-444.

19. Grealish G, Fitzpatrick R, Ringrose-Voase A, Hicks W: Brunei: Summary of Acid Sulfate Soils. Perth, Australia: 2008

20. Brunei Shell Petroleum Company Sendrian Berhard, Brunei Museum /Brunei Darussalam: The geology and hydrocarbon resources of Negara Brunei Darussalam. 2nd edition. Edited by Sandal ST. Syabas; 1996. ISBN 9991790004, 9789991790008.

21. MacDonald DD, Carr RS, Eckenrod D, Greening H, Grabe S, Ingersoll CG, Janicki S, Janicki T, Lindskoog RA, Long ER, Pribble R, Sloane G, Smorong DE: Development, evaluation, and application of sediment quality targets for assessing and managing contaminated sediments in Tampa Bay, Florida. Arch Environ Contam Toxicol 2004, 46:147-161.

22. Bush RT, Sullivan LA, Fyfe D, Johnston S: Redistribution of monosulfidic black oozes by floodwaters in a coastal acid sulfate soil floodplain. Aust $J$ Soil Res 2004, 42:603-607.

23. Clark MW, McConchie D, Lewis DW, Saenger P: Redox stratification and heavy metal partitioning in Avicennia-dominated mangrove sediments: a geochemical model. Chem Geol 1998, 149:147-171.

24. Abril G, Etcheber H, Delille B, Frankignoulle M, Borges AV: Carbonate dissolution in the turbid and eutrophic Loire estuary. Mar Ecol Prog Ser 2003, 259:129-138.

25. Marshall DJ, Santos JH, Leung KM, Chak WH: Correlations between gastropod shell dissolution and water chemical properties in a tropical estuary. Mar Environ Res 2008, 66:422-429.

26. Chua TE, Chou LM, Sadorra MSM (Eds): The Coastal Environmental Profile of Brunei Darussalam: Resource Assessment and Management Issues, Wokring Papers. Penang, Malaysia: The Worldfish Center; 1987.

27. Howland RJ, Tappin AD, Uncles RJ, Plummer DH, Bloomer NJ: Distributions and seasonal variability of $\mathrm{pH}$ and alkalinity in the Tweed Estuary, UK. Sci Total Environ 2000, 251-252:125-138.

28. Loreau M, de Mazancourt C: Biodiversity and ecosystem stability: a synthesis of underlying mechanisms. Ecol Lett 2013, 16(Suppl 1):106-115.

29. Telesh I, Schubert H, Skarlato S: Life in the salinity gradient: discovering mechanisms behind a new biodiversity pattern. Estuar Coast Shelf Sci 2013, 135:317-327

30. Worm B, Barbier EB, Beaumont N, Duffy JE, Folke C, Halpern BS, Jackson JB, Lotze HK, Micheli F, Palumbi SR, Sala E, Selkoe KA, Stachowicz JJ, Watson R: Impacts of biodiversity loss on ocean ecosystem services. Science 2006, 314:787-790.

31. Feely RA, Sabine CL, Lee K, Berelson W, Kleypas J, Fabry VJ, Millero FJ: Impact of anthropogenic $\mathrm{CO} 2$ on the $\mathrm{CaCO} 3$ system in the oceans. Science 2004, 305:362-366.

32. Waldbusser GG, Salisbury JE: Ocean acidification in the coastal zone from an organism's perspective: multiple system parameters, frequency domains, and habitats. Ann Rev Mar Sci 2014, 6:221-247.
33. Chao A: Non-parametric estimation of the number of classes in a population. Scand J Stat 1984, 11:265-270.

34. Harris JK, Caporaso JG, Walker JJ, Spear JR, Gold NJ, Robertson CE, Hugenholtz P, Goodrich J, McDonald D, Knights D, Marshall P, Tufo H, Knight R, Pace NR: Phylogenetic stratigraphy in the Guerrero Negro hypersaline microbial mat. ISME J 2013, 7:50-60.

35. Bolhuis $H$, Fillinger $L$, Stal $L$ : Coastal microbial mat diversity along a natural salinity gradient. PLoS One 2013, 8:e63166

36. Bolhuis H, Cretoiu MS, Stal LJ: Molecular ecology of microbial mats. FEMS Microbiol Ecol 2014, doi:10.1111/1574-6941.12408.

37. Sogin ML, Morrison HG, Huber JA, Mark Welch D, Huse SM, Neal PR, Arrieta JM, Herndl GJ: Microbial diversity in the deep sea and the underexplored "rare biosphere". Proc Natl Acad Sci U S A 2006, 103:12115-12120.

38. Bolhuis $\mathrm{H}$, Stal $\amalg$ : Analysis of bacterial and archaeal diversity in coastal microbial mats using massive parallel 16S rRNA gene tag sequencing. ISME J 2011, 5:1701-1712.

39. Zhang W, Ki JS, Qian PY: Microbial diversity in polluted harbor sediments I: bacterial community assessment based on four clone libraries of 16S rDNA. Estuar Coast Shelf Sci 2008, 76:668-681.

40. Toes AC, Finke N, Kuenen JG, Muyzer G: Effects of deposition of heavymetal-polluted harbor mud on microbial diversity and metal resistance in sandy marine sediments. Arch Environ Contam Toxicol 2008, 55:372-385.

41. Hughes JB, Hellmann JJ, Ricketts TH, Bohannan BJM: Counting the uncountable: Statistical approaches to estimating microbial diversity. Appl Environ Microb 2001, 67:4399-4406

42. Sahoo K, Dhal NK: Potential microbial diversity in mangrove ecosystems: a review. Indian J Mar Sci 2009, 38:249-256.

43. Wang Y, Sheng HF, He Y, Wu JY, Jiang YX, Tam NF, Zhou HW: Comparison of the levels of bacterial diversity in freshwater, intertidal wetland, and marine sediments by using millions of illumina tags. App/ Environ Microbiol 2012, 78:8264-8271.

44. Watermann F, Hillebrand H, Gerdes G, Krumbein WE, Sommer U: Competition between benthic cyanobacteria and diatoms as influenced by different grain sizes and temperatures. Mar Ecol Prog Ser 1999, 187:77-87.

45. Rinke C, Schmitz-Esser S, Stoecker K, Nussbaumer AD, Molnar DA, Vanura K, Wagner M, Horn M, Ott JA, Bright M: "Candidatus Thiobios zoothamnicoli," an ectosymbiotic bacterium covering the giant marine ciliate Zoothamnium niveum. Appl Environ Microbiol 2006, 72:2014-2021.

46. Neutzling O, Pfleiderer C, Trüper HG: Dissimilatory sulphur metabolism in phototrophic non-sulphur bacteria. J Gen Microbiol 1985, 131:791-798.

47. Selig ER, Turner WR, Troeng S, Wallace BP, Halpern BS, Kaschner K, Lascelles BG, Carpenter KE, Mittermeier RA: Global priorities for marine biodiversity conservation. PLoS One 2014, 9:e82898.

48. Lohman DJ, de Bruyn M, Page T, von Rintelen $\mathrm{K}$, Hal R, Ng PKL, Shih HT, Carvalho GR, von Rintelen T: Biogeography of the Indo-Australian Archipelago. Annu Rev Ecol Evol S 2011, 42:205-226.

49. Sulaiman ZH, Mayden RL: Cypriniformes of borneo (Actinopterygii, otophysi): an extraordinary fauna for integrated studies on diversity, systematics, evolution, ecology, and conservation. Zootaxa 2012, 3586:359-376

50. Garbutt N, Prudente JC: Wild Borneo: The Wildlife and Scenery of Sabah, Sarawak, Brunei and Kalimantan. Cambridge, Mass: MIT Press; 2006:176

51. Wong KM, Chan CL: Mount Kinabalu: Borneo's Magic Mountain: An Introduction to the Natural History of One of the World's Great Natural Monuments. Kota Kinabalu: Natural History Publications; 1997.

52. Rohde K: Latitudinal gradients in species-diversity - the search for the primary cause. Oikos 1992, 65:514-527.

53. Martiny JBH, Eisen JA, Penn K, Allison SD, Horner-Devine MC: Drivers of bacterial $\beta$-diversity depend on spatial scale. Proc Natl Acad Sci 2011, 108:7850-7854

54. Zhang Y, Zhao Z, Dai M, Jiao N, Herndl GJ: Drivers shaping the diversity and biogeography of total and active bacterial communities in the South China Sea. Mol Ecol 2014, 23:2260-2274.

55. Hanson CA, Fuhrman JA, Horner-Devine MC, Martiny JB: Beyond biogeographic patterns: processes shaping the microbial landscape. Nat Rev Microbiol 2012, 10:497-506.

56. de Bruyn M, Ruber L, Nylinder S, Stelbrink B, Lovejoy NR, Lavoue S, Tan HH, Nugroho E, Wowor D, Ng PK, Siti Azizah MN, Von Rintelen T, Hall R, Carvalho GR: Paleo-drainage basin connectivity predicts evolutionary relationships across three Southeast Asian biodiversity hotspots. Syst Biol 2013, 62:398-410. 
57. Stein A, Gerstner K, Kreft H: Environmental heterogeneity as a universal driver of species richness across taxa, biomes and spatial scales. Ecol Lett 2014, 7:866-880.

58. Miyashita NT, Iwanaga H, Charles S, Diway B, Sabang J, Chong L: Soil bacterial community structure in five tropical forests in Malaysia and one temperate forest in Japan revealed by pyrosequencing analyses of 16S rRNA gene sequence variation. Genes Genet Syst 2013, 88:93-103.

59. Raes N, Roos MC, Slik JWF, van Loon EE, ter Steege H: Botanical richness and endemicity patterns of Borneo derived from species distribution models. Ecography 2009, 32:180-192.

60. Hossain MB, Marshall DJ, Venkatramanan S: Sediment granulometry and organic matter content in the intertidal zone of the Sungai Brunei estuarine system, northwest coast of Borneo. Carpath J Earth Env Sci 2014, 9:231-239.

61. Edwards U, Rogall T, Blocker H, Emde M, Bottger EC: Isolation and direct complete nucleotide determination of entire genes. Characterization of a gene coding for $16 \mathrm{~S}$ ribosomal RNA. Nucleic Acids Res 1989, 17:7843-7853.

62. Lane DJ: $16 \mathrm{~S} / 23 \mathrm{~S}$ rRNA sequencing. In Nucleic Acid Techniques in Bacterial Systematics. Edited by Stackebrandt E, Goodfellow M. Chichester, United Kingdom: John Wiley and Sons; 1991:115-175.

63. Nubel U, Engelen B, Felske A, Snaidr J, Wieshuber A, Amann RI, Ludwig W, Backhaus H: Sequence heterogeneities of genes encoding $16 \mathrm{~S}$ rRNAs in Paenibacillus polymyxa detected by temperature gradient gel electrophoresis. J Bacteriol 1996, 178:5636-5643.

64. Piquet AM, Bolhuis H, Davidson AT, Thomson PG, Buma AG: Diversity and dynamics of Antarctic marine microbial eukaryotes under manipulated environmental UV radiation. FEMS Microbiol Ecol 2008, 66:352-366.

65. Quast C, Pruesse E, Yilmaz P, Gerken J, Schweer T, Yarza P, Peplies J, Glockner FO: The SILVA ribosomal RNA gene database project: improved data processing and web-based tools. Nucleic Acids Res 2013, 41:D590-D596.

66. Schloss PD, Westcott SL, Ryabin T, Hall JR, Hartmann M, Hollister EB, Lesniewski RA, Oakley BB, Parks DH, Robinson CJ, Sahl JW, Stres B, Thallinger GG, Van Horn DJ, Weber CF: Introducing mothur: open-source, platformindependent, community-supported software for describing and comparing microbial communities. Appl Environ Microbiol 2009, 75:7537-7541.

doi:10.1186/2046-9063-10-10

Cite this article as: Bolhuis et al:: Molecular analysis of bacterial diversity in mudflats along the salinity gradient of an acidified tropical Bornean estuary (South East Asia). Aquatic Biosystems 2014 10:10.

\section{Submit your next manuscript to BioMed Central and take full advantage of:}

- Convenient online submission

- Thorough peer review

- No space constraints or color figure charges

- Immediate publication on acceptance

- Inclusion in PubMed, CAS, Scopus and Google Scholar

- Research which is freely available for redistribution 